\title{
Social Remembering, Disenchantment and First World War Literature, 1918-1930
}

\author{
Andrew Frayn, Edinburgh Napier University
}

\begin{abstract}
The way that the First World War would be remembered was yet to be solidified in the years immediately after the Armistice and peace treaties. Using key case studies from the years 1918 to 1930 by combatant authors Gilbert Frankau, Ernest Raymond, C.E. Montague, R.C. Sherriff and Richard Aldington, this article charts the development of the complex relationship between the dominant heroic mode and emergent modern disenchantment. Theories of social remembering provide a valuable framework for understanding the social processes by which disenchantment became a, if not the, widely-held memory of the conflict, reaching acceptance in the War Books Boom that followed the dual successes of Erich Maria Remarque's Im Westen Nichts Neues, first serialised on the tenth anniversary of the armistice, and Sherriff's Journey's End, first performed the following month.
\end{abstract}

Keywords: disenchantment, First World War literature, heroic mode, memory studies, social remembering, War Books Boom, war writing

The social memory of the First World War changed dramatically in the decade and a half between its start and the height of the War Books Boom of 1928-1930: the international successes of Erich Maria Remarque’s Im Westen Nichts Neues, first serialised on the tenth anniversary of the of the Armistice, and R.C. Sherriff's Journey's End, first performed the following month, led to widespread reconsideration of the war's worth and an outpouring of cultural production about the conflict, particularly in the UK. Initially, the dominant public rhetoric had been of heroism, patriotism and sacrifice, epitomised by poets such as Rupert Brooke and Jessie Pope. Poems such as Julian Grenfell’s (1915: 9) ‘Into Battle’—which includes the lines 'he is dead who will not fight / And who dies fighting has increase'-were given added poignancy by the knowledge of the author's death in service. Representations of war diverged throughout the 1920s; while this mode remained popular, key texts of the War 
Books Boom such as Robert Graves’s Goodbye to All That (1929) and Siegfried Sassoon’s Sherston trilogy (1928-1936) are disenchanted with aspects of military service and wartime experience. Barbara S. Misztal (2003: 45) argues that 'the war’s myth [was] supplied with coherence by literary narratives', while James V. Wertsch (2002: 54), a key theorist of collective memory, astutely notes that 'the cultural tools we employ to remember something like the bombing of Hiroshima or World War I themselves have a sort of memory, or at least memory potential, built into them'. Remembering these defining historical moments is ongoing work bound up in social processes; disenchantment cannot come only from wartime experience. Previous work has engaged with the changing shape of memory in the interwar period focusing on irony in poetry (Fussell, 1975), the middlebrow novel (Bracco, 1993) and a broad range of cultural production (Hynes, 1990; Stevenson, 2013). I explicitly chart the development of the disenchanted mode in disparate prose works of the post-war decade, using a framework of theories of social remembering.

\section{Social remembering}

The lack of critical consensus on terminologies of memory means that clarity about one's own choices is vital. I use social remembering to describe the ongoing act of processing and reprocessing, and social memory to describe completed works of memory. In this I follow James Fentress and Chris Wickham (1992), Misztal, and Guy Beiner (2007: 29), who writes that 'it is probably best to speak of "social," rather than "collective,” locating remembrance within processes that are intrinsic to the normal functions of society.' These theorists acknowledge their indebtedness to Maurice Halbwachs’s $(1980,1992)$ theory of collective memory, itself rooted in European concerns in the interwar period: his pioneering Les cadres sociaux de la mémoire (The Social Frameworks of Memory) was published in 1925. Halbwachs observes: 'it is in society that people normally acquire their memories. It is also 
in society that they recall, recognize, and localize their memories. [ . . T]he groups of which I am a part at any time give me the means to reconstruct them' (1992: 38, Nora, 1996). Without recourse to existing narrative, epistemological and political frameworks, memory could not take place: we remember in constant dialogue with the language and myths that surround us. The narrative construction of memory means that the interest is not, for me, in the possibility of accurate recall (Clark and Stephenson, 1995), but in how memories shift. Hewer and Roberts (2012) point to the complex relationship between subjective reality and the social forces that shape memories, rejecting 'any notion of a fixed or absolute conception of the past' (2012: 180; Keightley and Pickering, 2012, ch.1). ${ }^{1}$ Like Barry Schwartz (2016) I retain a degree of unease about absolute constructionism, but I do see novels as memories 'in and not of the group' (Isurin, 2017: 12). Schwartz (2016: 11) reminds us, however, that memory is ‘a distributive entity whose key property is variation’: it endures by being rewritten, and participation in disparate interest groups means that it shifts shape. Julie Hansen (2015) observes that by its nature fiction licences authors to reconsider, and creative texts were vital in shifting discourse about the conflict in the post-war decade. While literary studies of memory tend to focus on the idea of cultural memory (Erll, 2011; Rigney, 2016), I accentuate the social to highlight literature's participation in broader trends and debates; there is no clear division between social and cultural memory (Olick, 2016).

Service in the mass volunteer and conscript armies of the First World War existed alongside other affiliations. Military training promotes homogeneity and enforces the strict hierarchical structure. The heightened emotional and physical experience of wartime makes it memorable (Zerubavel, 2003: 28), particularly perhaps for non-professional combatants (Winter and Sivan, 1999: 17). Social memory derives from groupings such as class, religion and family; members of modern societies participate in a variety of interest groups (Halbwachs, 1992; Hervieu-Léger, 2000: 129). Troops shared significant common 
experiences such as living conditions and viscera of war, but the army was a socially disparate group, in a society still stratified by class (de Groot, 1996: 19, 167). Troops from around the world served in this imperial conflict, adding racial and other cultural differences. While most troops were Christian on paper, not all were active believers. A recruiting office administrator brutally underlines the importance of religion in Richard Aldington's Death of a Hero (1929): 'Yer’ll want suthin' over yer fuckin’ grave in France, won’t yer? An’ yer’ll bloody well be in it in six months. No religion! Strike me fuckin’ pink!' (1965 [1929]: 239). Consolation seemed worthwhile, however limited. Despite the entrenched differences between the troops many prominent commemorative and campaigning groups and organisations such as the British Legion continued links to the military.

An unprecedented proportion of the population was affected by the First World War: the mobilised part of the population absent, the workforce reconfigured, supplies and services disrupted. The impact on the home front is registered in wartime non-combatant works such as H.G. Wells’s Mr Britling Sees It Through (1916), whose title highlights the continuing need for fortitude, and Rebecca West's The Return of the Soldier (1918), which depicts shell shock and its invidious cures. The emotional and physical privations of the war lingered, and the work of remembering was revealed in the painful processes of reintegration, for men who came back, and mourning, for those who did not. Halbwachs's translator Lewis A. Coser explicitly situates his work on social memory in this context (Halbwachs, 1992: 12). Fentress and Wickham (1992: 129) argue that the social memories of major historical events 'constitute discourses that are available to everybody, not just elites, and most people think and speak in terms of them.' The war is a shared referent which cannot become the exclusive property of any one group. New experiences were commonplace during the war, although the omnipresence of one fundamental human experience shifted its meaning: death (Winter, 1995: 79; Todman, 2005: 43). Hallam and Hockey (2001: 3) argue that 'death act[s] as a 
deep incentive to remember and the process of dying can give licence to intense phases of memory making with all of its attendant material complexity.' Along with killing and proximity to death, however, it is also an experience often viewed as incommunicable (Benjamin, 1999; Srubar, 2016: 26-27). Commemoration was everywhere in the post-war decade as new memorials were erected in workplaces, churches, schools, sports clubs, and other public spaces. These enduring changes made the work of remembering highly visible. Winter $(1995: 1,51)$ asserts that 'remembrance is part of the landscape', but also notes that: 'Commemoration also happened on a much more intimate level, through the preservation in households of possessions, photographs, [and] personal signatures of the dead.' Traces of the war in public and private spaces meant that while some aspects of memorialisation became codified, people carried on remembering and reappraising.

\section{Disenchantment}

Those reappraisals are often linked with the commonplace that literature about the First World War is characterised by disenchantment, or disillusionment. Few scholars have attempted to define the term with any precision: it usually stands implicitly for retrospective combatant discontent (Buitenhuis, 1987; Martin, 1999; Eksteins, 2000; Watson, 2004). However, disenchantment should be understood within ongoing discourses of decline and discontent which can be traced back to Charles Darwin’s The Descent of Man (1871), through Max Nordau’s Degeneration (1892, trans. 1895), C.F.G. Masterman’s concerns about The Condition of England (1909), up to the late- and post-war analyses of Max Weber, in various essays, and Oswald Spengler in The Decline of the West (1918-1922, trans. 19261928) (Pick, 1989). Disenchantment derives from the clash between abstraction and lived reality in rationalised bureaucratic modernity (Leed, 1979). It was not solely a combatant issue, but a societal problem that found a focus for its expression in writing about the First 
World War, the paradigmatic mass experience of the age. Political and economic instability in post-war Britain meant that the grand promises made to returning combatants, exemplified by Lloyd George’s promise to create a 'fit country for heroes to live in', proved impossible to carry out (Anon, 1918a; Anon, 1918b). Distrust towards official proclamations developed following the experience of wartime propaganda. Changes of government were frequent and industrial action was regular, culminating in the General Strike of 1926. A condition of modernity, the expression of disenchantment only gradually becomes an accepted narrative of the war (Frayn, 2014). It was also not without mitigation: many authors continued to see value in the homosocial bonds formed by military service. To be disenchanted presupposes an initial enchantment; for many, this was a dialectical relationship (Saler, 2006).

I chart the push and pull of social remembering in the aftermath of the First World War via five brief case studies which illustrate uneven narrative development. Gilbert Frankau's Peter Jackson, Cigar Merchant (1919) remains heroic and consolatory; it and Ernest Raymond's Tell England (1922), a public school novel whose title is an effective synopsis, were two of the bestselling post-war works about the conflict. Raymond's novel was published in the same month as C.E. Montague’s contrasting Disenchantment (1922). R.C. Sherriff's Journey's End (1928) complicated heroic narratives while retaining a loyalty to them; along with All Quiet on the Western Front, it was a key text in stimulating the War Books Boom, of which Richard Aldington’s Death of a Hero (1929) was an early and extreme example. These combatant works tread a line between memoir and fiction as they participate in the ongoing social remembering of the conflict. Wertsch posits that 'collective memory also undergoes change over time [... It] emerges in response to the need to create a usable past' (2002: 45). These literary works illustrate changes over a relatively brief period, as the function of memories of the conflict shifted from consolation to critique. 


\section{Frankau, healing and heroism}

Wartime service is still remembered as heroic in Gilbert Frankau’s Peter Jackson, Cigar Merchant. Frankau was a successful war poet, a patriot whose beliefs are epitomised by his short-lived journal Britannia (1928). The novel is conservative but forward-thinking, its inconsistencies demonstrating the mess of immediacy as narratives about the war were yet to be solidified. Muscularity and stoicism are desirable characteristics and heroism in traditional forms is still prized, if not without question. War gives public-school educated men a focus for the masculinity they attained on graduation, a reason to remember those supposed halcyon days, and the facility to reflect on their training. The eponymous protagonist is a product of that system, and the narrator comments, perhaps not without irony: 'Luckily, there is no "education” at English public-schools. They merely train boys to be men’ (Frankau, 1919: 198). A month into the war he tells his wife, Pat: “'I don't think I can keep out of this thing any longer. It wouldn't be”-he fumbled for the expression— “quite playing the game.”' The allusion to Henry Newbolt's 'Vitaï Lampada', the quintessential expression of the public school ethos via sport and war, points to the importance of social memory for this group in supporting the war. Bracco (1993: 71) asserts that the novel 'pivots around the aggressive assertion of a patriotic imperative, which is articulated through reference to icons of class value.' Repression is evident in the business-like marital communications: Pat can only acknowledge internally the reality of the situation: 'her heart cried out in her. "He's going. He’s a man. What else matters?”' (both Frankau, 1919: 62). To verbalise her concerns is taboo, and it would be against Peter's view of her as 'a topping pal' to cavil or demur at his decision (Frankau, 1919: 63). Military service is the only thing to be done, and men like Peter perform masculinity semi-consciously. In the novel it is possible to be unmanly only in extremis, and even then the reinstatement of physical strength is possible as a result of mental fortitude. 
Recovery is aligned with the restoration of the pre-war family unit. Peter and Francis Gordon, his cousin, each receive a serious wound which removes him from active service. In this novel, injuries accruing from the war are bodily memories which can be forgotten, or at least hidden. Wounded or not, combatants were often left with bodily memories of the conflict as they became slimmer, more muscular, changed complexion or skin condition because of the change from clerical to manual work. Shell shock is not here fully understood: it seems only to need a good woman to sort it out. The recoveries of Peter and Francis are substantially completed, and relationships, with wife and lover respectively, improved by the test endured. The resurrection of the family unit through the strong and uninjured woman is key: 'These were not lunatics, but two sufferers, two sick men. And she, Patricia, would cure them both. To cure, to heal—-these were the functions of her womanhood. ...' (Frankau, 1919: 347-348). In the final action of the novel before its epilogue, she prays to give Peter a son and ensure patrilinear succession. This, of course, succeeds. In a similarly conservative narrative strategy, Francis Gordon’s worries about being unmanned (Frankau, 1919: 206) dissipate when he embraces religion in a moment of hatred and doubt (Frankau, 1919: 371). Along with the reunion with his American fiancée, this gives him the wherewithal to recover: 'apparently this tender "bossing” was just the one thing needful to Francis Gordon’s temperament. He expanded under it; became positively human. His very physique seemed to improve: the hopeless shuffle became a mere limp: he carried his head erect, his shoulders unbowed' (Frankau, 1919: 374). The return is complete, for all involved, to a distantly remembered previous state in which strength of body, community and faith are intact. Hopelessness is defeated and purpose found in the restoration of the family group; Jay Winter has highlighted the importance of family and kinship in recovery and consolation (1995: 29-30). 
War is still remembered as a victory in Peter Jackson, Cigar Merchant, albeit balanced with recognition of the number of deaths. Celebration is still an acceptable social memory of the conflict's end: the novel was first serialised from late August 1919 and published in volume form the same December. The novel’s epilogue recounts a joyous motor-ride to London to celebrate the Armistice. To the reader accustomed to cinematic tropes, the scene has the jarring feel of a car chase: 'Peter took one deep breath; fidgeted throttle-lever full open; jammed foot on accelerator' (Frankau, 1919: 396). The terse, imperative, grammatically incorrect actions make the necessity for haste clear: this is a race to victory. They make it to Piccadilly on the stroke of $11 \mathrm{am}$, to be greeted by exuberant celebrations:

Pandemonium! Everybody was dancing. The flags were dancing. Men and women were dancing. Soldiers were dancing—English soldiers and American soldiers, French soldiers and Belgian soldiers, Portuguese and Japanese and Italian soldiers—lame soldiers and legless soldiers and armless soldiers—ill soldiers and well soldiers. Sailors were dancing—English sailors and American sailors, French sailors and Italian sailors and Japanese sailors. The very houses were dancing: floods of white paper came dancing down out of the dancing houses. Their own car was dancing: her cushions were dancing: they could feel her engine dancing. They themselves were dancing: they could feel their hearts dancing inside them: the blood was dancing in their veins, dancing and dancing. . . . (Frankau, 1919: 399)

The repeated vocabulary of this penultimate paragraph declares that these celebrations belong to those who fought. Although the novel's final paragraph alludes obliquely to war's human cost, victory is acclaimed and the conflict valued positively. This is the initiating moment of ongoing public commemoration, which is key in social remembering (Isurin, 2017: 24-25). The solemnity of Armistice Day was yet to be conceived: silence was a late addition to the 1919 ceremony (Gregory, 1994: 8-18), and the decision to make the Cenotaph permanent was yet to be publicly announced (Gregory, 2008: 266-267). The Manchester Guardian 
reported widespread celebratory events as late as 1925, if in the context of a 'sharp difference of opinion as to the fittest way of keeping that great anniversary' (Anon, 1925).

Remembering the First World War as a victory quickly became taboo.

\section{Raymond, sport and sacrifice}

Even several years later, popular narratives about the war remember it as a necessary, heroic sacrifice. Ernest Raymond's Tell England makes clear the desirability of patriotism and devotion to the King as head of the army, state, and church. Illusions that were already beginning to wane still hold sway here. A public-school educated clergyman, Raymond unsurprisingly situates a Christian metanarrative within military history; he uses terms that bridge sporting and military discourse, locating himself within the public school ethos. The narrator connects school, sport and war:

\footnotetext{
It was on the day when those two pistol-shots were fired at an Austrian Archduke in the streets of Serajevo that the Masters' match was played out at Kensingtowe. [... W]hile the Emperors of Central Europe were whispering that the Day had come and the slaughter of the youth of Christendom might begin, there was a gathering in Radley's room of those insignificant people whose little doings you have watched at Kensingtowe.
} (Raymond, 1922: 155)

The analogy for war is cricket. Radley has already coached the juvenile protagonist Rupert Ray out of a nasty habit of 'stepping back' while batting (Raymond, 1922: 100), and then the protagonist's nervous courage as a bowler leads the student team to an innings victory over the masters. The challenge to authority is contained immediately as both sides come together to celebrate. Once enlisted, the danger to young men is acknowledged, but individual excellence and collective fortitude are prized. In Ray’s wholesome world, a wellled life leads to a 'good death'. His friend Edgar Doe suggests that 'the romantic genius of Britain is beginning to see the contour of Gallipoli invested with a mist of sadness, and 
presenting an appearance like a mirage of lost illusions' (Raymond, 1922: 248). He overcomes his reservations, however, and dies resolutely, his last words being: ‘Well, it can’t be helped. If I'd known when I started that it would end like this-I'd have gone through with it just the same. I haven't got cold feet' (Raymond, 1922: 296). The doubts occasioned in Ray are quickly contained by Padre Monty, the chaplain of Ray's public school and army section who is also the purported 'editor' of the volume: 'Had there been no war, you'd have left school and gone your different roads, till each lost trace of the other. It's always the same. But, as it is, the war has held you in a deepening intimacy till—-till the end. It's—it's perfect' (Raymond, 1922: 300). Shared experience in the service of the nation is perfection, and the perpetual ellipsis of death is subtly indicated by the halting em dashes. Consolation remains important: the promise of redemption and rebirth swiftly negates the potential for resistance. Ray re-engages with his faith, and the portentous final section leaves little doubt about his fate: 'Oh, but if I go down, I want to ask you not to think it anything but a happy ending. It will be happy, because victory came to the nation, and that is more important than the life of any individual' (Raymond, 1922: 319). The need for collective action and selfeffacement is highlighted as Ray reflects on his twenty well-lived years, and the social memory of the war as just is reiterated. Jay Winter points out the 'overlap of languages and approaches between the old and the new', and argues 'that the enduring appeal of many traditional motifs - defined as an eclectic set of classical, romantic, or religious images and ideas - is directly related to the universality of bereavement in the Europe of the Great War and its aftermath' $(1995: 3,5)$. This attests to the central paradox of remembering the First World War, and wartime in general: the competing strands of the desire to reconnect with the pre-war world, and the desire to start anew at its conclusion (Dudziak, 2012). As fiction about the conflict becomes more critical during the post-war decade, the narrative of earthly virtue leading to heavenly reward is rejected, rather than fleetingly challenged. 


\section{Montague, enchantment and disenchantment}

C.E. Montague’s Disenchantment appeared in the same month as Tell England. Their radical difference, however, is evident in title, form, commercial success and critical acclaim. A journalist for the Manchester Guardian, invested in that paper’s liberal ethos, Montague supported the war from its early days, while his colleagues were initially sceptical. He dyed his hair to enlist at 47, four years over the maximum age for recruitment at the time: H.W. Nevinson later wrote poetically that 'Montague is the only man I know whose white hair in a single night turned dark through courage’ (1928: 139). Like many older combatants, he was in the front line only for a short time, from November 1915 to February 1916, when he was told that his age could no longer be overlooked (Elton, 1929: 98). Having been enthused by the dangers of front-line service he was frustrated, but experienced a wide range of duties as Intelligence Officer, guiding front-line tours, writing official war articles, encountering distinguished guests and civilian visitors. Engagement with this unusual variety of viewpoints nuanced further his already liberal position. Disenchantment foregrounds the problem of reconciling the heroic mode with the physical experience of modern war, and Montague discerned the emergence of a different narrative. Traditional forms no longer seemed appropriate to an increasing number of questioning authors. Montague does not moralise through fiction, and his understated style, reflecting the gravity and freshness of memories of the conflict, is an exercise of discerning judgment. In the opening chapter of Disenchantment he reflects:

\footnotetext{
Now that most of our men in the prime of life have been in the army we seem to be in for a godly literature of disappointment. All the ungifted young people came back from the war to tell us that they were "fed up." That was their ailment, in outline. The gifted ones are now coming down to detail. (Montague, 1922: 1)
} 
Montague outlines the shifting social memory of the war. However, the new literary mode he foresaw was slow to appear, with stories about the difficulty of post-war composition commonplace. ${ }^{2}$ The metaphor Halbwachs (1992: 46-47) uses of returning to a favoured childhood book is salutary: the hold of previous enchantments is loosened and the conditions for disenchantment were always present. Montague’s work proved influential within literary circles, noticed by other authors and showing the possibility for the expression of discontent.

Disenchantment is an early work to consistently criticise the war, its literate style and unusual prose form catalysing a reshaping of the acceptable social memory of the conflict. The ur-text of post-war literary disenchantment, its title points to the ongoing work of remembering. The aesthetic form of Disenchantment is unusual in terms of its structure and prose style: it is essentially an essay collection with a chronological progression. Perhaps best likened to memoir, it is neither explicitly factual nor fictional. The formal obscurity facilitates the presentation of material which starts to pose uncomfortable questions about wartime experience and conduct. The prolix, elaborate and measured nature of his style also facilitated the publication of a relatively critical message at a time when writing such as Raymond's still dominated the mass market, but limited its wider impact. Montague was a noted prose stylist, a novelist and drama critic before the war; A.C. Ward recognised, in The Nineteen-Twenties that 'his literary urbanity softened the attack' (1930: 11). He references Shakespeare, Arnold, Swinburne and Burke, and uses French and Latin tags, situating this as a discourse of and for the elite: 'And yet it remains where it was, like the plucked Golden Bough: uno avulso, non deficit alter, ready as ever to work on a guileless mind like our friend's’ (Montague, 1922: 75). In the same chapter Montague is aware of cultural superiority, commenting dismissively on ‘a typical working-class Englishman, literal, serious, and straight, [who] had not got one loop of subtlety or one vibration of irony in his whole mind' (Montague, 1922: 74). He remembers the value of camaraderie across classes in 
the Army, but his elevated style indicates that this memory of the war is for a restricted audience. However, he challenges the prevailing social memory in an unfamiliar aesthetic form, and his existing high reputation ensured that his work was valued by public intellectuals and opinion-formers. Fentress and Wickham (1992: 201-2) assert that 'social memory seems to be subject to the law of supply and demand. Memories must be supplied; they must emerge at specific points. Yet, to survive beyond the immediate present, and, especially, to survive in transmission and exchange, they must also meet a demand'. Demand accrued from Montague's literary status, and the acceptance of these views was facilitated by the fact that much of the volume was revised from Manchester Guardian leaders (Grieves, 1997).

\section{Disenchantment develops}

Montague's work did not reshape war literature as he anticipated, although the conflict remained a popular subject. The middle period of the decade saw writers searching for appropriate forms to represent the conflict. Notable were Ford Madox Ford's Parade’s End tetralogy (1924-1928; single-volume edition 1950), and R.H. Mottram’s The Spanish Farm Trilogy (1924-1926; single-volume edition 1927). These show the overlap between old and new that Winter identifies, and update the saga form made fashionable by Galsworthy’s Forsyte Saga (1906-1921; single-volume edition 1922), which barely mentions the war (Hynes, 1990, 329-331). Ford and Mottram approach the war from very different points of view. Ford evokes powerfully the unstable temporal experience of war, moving from stasis to intense danger (Haslam, 2002). He depicts, unusually, the world before, during and after the war, and situates it in a long history, his wilfully anachronistic gentleman-soldier-hero Christopher Tietjens propounding eighteenth-century Tory values. By contrast, Mottram’s three novels all deal only with wartime experiences, intersecting around the titular location. 
The epic scale of these multi-volume works allows the authors to illustrate the push and pull of social remembering. Both achieved some commercial success and Mottram’s trilogy finally abled him to become a professional author. The series was critically acclaimed: his mentor Galsworthy introduced The Spanish Farm, and it won the Hawthornden Prize for 1924. Gerald Bullett (1925) noted in the Times Literary Supplement 'a spirit of disillusionment but not of bitterness'; Montague wrote to their shared publisher, Chatto \& Windus, in praise of the trilogy. ${ }^{3}$ The response to Ford was more mixed. The Daily Mail reviewer of the first volume, Some Do Not..., called it 'one of his cleverest and grimmest studies of mankind' (Anon, 1924); L.P. Hartley (1926) wrote that 'applied to the war, it imparts the right febrile atmosphere.' Hugh Walpole (1925), Rachel Annand Taylor (1928) and Cyril Connolly (1928) were also complimentary. The success, albeit limited, of these novels which question the validity of the heroic mode shows the uneven process of social remembering.

Disenchantment starts to become accepted as a popular narrative of the war in response to the international success of Erich Maria Remarque's Im Westen Nichts Neues (All Quiet on the Western Front, 1929) (Eksteins, 1980). Janet S.K. Watson observes that 'the story of disillusionment had clearly been present for some time. Now, however, it would catch a new generation of readers and convince them, despite a hurricane of debate, of the significance of the war' (2004: 194). The serialisation of Remarque’s novel started in Germany on the tenth anniversary of the Armistice, with mystique created by a 'flamboyant and expensive advertising campaign' (Eksteins, 2000: 286). It was a controversial popular success, stimulating demand around the world for translations. It was no longer the case that the main understanding of the war was based on quintessentially English but now outdated values of chivalry, honour, and sacrifice. It rapidly became acceptable to espouse a social memory based on Remarque’s emphatic reaction against German militarism, which drew on 
the experience of a defeated nation. The success of All Quiet on the Western Front stimulated the market for all forms of literature and culture that remembered the conflict.

\section{Sherriff, heroism and survival}

R.C. Sherriff's play Journey's End was the British success that, along with Remarque’s novel, stimulated the War Books Boom, and it exemplifies how textual interpretation is shaped by social remembering. Running for a year and a half at the Savoy, it was one of the last great successes before cinema became the dominant visual medium, albeit a surprising one (Bracco, 1993: ch. 5; Walters, 2016). Key to its success was that its lack of overt moralising offered audiences the chance for divergent interpretations. In some respects Journey's End sits comfortably alongside earlier works such as Tell England and Peter Jackson, Cigar Merchant. The alcoholic protagonist Stanhope proclaims: 'Hero-worship be damned!' (Sherriff, 2000 [1929]: 33), but it remains. The appearance of Raleigh, the younger brother of his girlfriend, jolts him, not least because of his knowledge that he is being idolised as an older brother, the captain of sports teams, and a public school hero. Stanhope needs to drink to keep going, but does so and stays in the trenches: it is imperative to carry on. His treatment of the deserter Hibbert shows limited compassion for a reaction against war's brutality:

\footnotetext{
You may be wounded. Then you can go home and feel proud—and if you're killed you—you won't have to stand this hell any more. I might've fired just now. If I had you would have been dead now. But you're still alive-with a straight fighting chance of coming through. Take the chance, old chap, and stand in with Osborne and Trotter and Raleigh. (Sherriff, 2000 [1929]: 58)
}

While Stanhope acknowledges the hellish situation, his response to Hibbert's desire to subvert military authority is to quash the rebellion. The defence of the nation and 
commitment to the group is more important than individual survival, although Stanhope attempts to assert individual agency: 'I mean to come through—don't you?' (Sherriff, 2000 [1929]: 59). Despite its billing on the back cover of the current Penguin edition as 'a great anti-war classic', there is never any suggestion that it is not right to serve. Indeed, Sherriff (1968: 73) later pointed out that it was 'a war play in which not a word was spoken against the war, in which no word of condemnation was uttered by any of its characters'. While ultimately doubt is contained, its presence in the form of Stanhope's alcoholism and Hibbert's desire to desert signalled a radical revisioning of heroism as social remembering transformed war narratives. Not only is the expression of such positions acceptable, but a play which upholds masculine values of stoicism and fortitude can be seen as anti-war. Fentress and Wickham (1992: 58) explain that 'in continuous experience, memory overlays memory. The transmission of narrative is marked by this process as well. It is a process, however, which covers its own tracks.' In Journey’s End the layering of different memories of the war is clear, the disenchantment that Montague describes enacted subtly while loyalty to conservative values is maintained.

\section{Aldington, trauma and guilt}

That Sherriff and Remarque had reshaped the social memory of the war was clear to other authors. Richard Aldington was working on his war novel Death of a Hero (1929) as these twin successes took hold and he was acutely conscious of the commercial opportunity (Trott, 2016). As Wertsch (2002: 50) notes, 'accounts come into existence through being exposed to the textual resources provided by others.' Aldington's novel is bitingly satirical about the Victorians and his fellow Imagists, scathing about the post-war world reactions to it, and profane to the extent of needing expurgation to be published. Disenchantment has become an, if not the, accepted narrative: death is no longer glorious sacrifice, martyrdom, or even a 
sad truth of the war, but is remembered as 'murder'. The narrator lambasts the cant of previous generations and criticizes civilian complicity:

Why all this fuss over a few million men killed and maimed? Thousands of people die weekly and somebody's run over in London every day. Does that argument take you in? Well, the answer is that they're not murdered. And your "thousands who die weekly" are the old and the diseased; here it's the young and the strong and the healthy, the physical pick of the race. [...] It doesn't matter whether murder is individual or collective, whether committed on behalf of one man or a gang or a state. It's murder. When you approve of murder you violate the right instincts of every human being. And a million murders egged on, lauded, exulted over, will raise a legion of Eumenides about your ears. (Aldington, 1965 [1929]: 244-245)

The fulminating, vitriolic tone is characteristic of similar passages in the voice of Aldington's narrator before the final 'war' section. For Stevenson (2013: 105) it is 'almost as much essay as novel.' The staccato sentences and generally plain language (barring the invocation of the Eumenides, the Greek Furies) spell out the harsh message clearly. Young, athletic men had been encouraged to serve, and their loss was now bemoaned by the bitter survivors, some of whom were the elders and supposed betters who had condemned them. Janet S.K. Watson (2004: 203) states that 'one of the important characteristics of the story of disillusionment [is] the gap in understanding between young people and their parents' generation.' The contrast with Montague’s elliptical phrasing and high diction, and Raymond's muscular Christian heroism is striking.

The narrator’s agonies come partly from these generational inequalities in the war effort, and partly from survivor guilt. The spectre of war haunts survivors, traumatic memories intruding as the narrator asserts that 'writing the life of George Winterbourne [. . . ] is an atonement, a desperate effort to wipe of the blood-guiltiness' (Aldington, 1965 [1929]: 36). He feels that in surviving he has transgressed: 
What right have I to live? Is it five million, is it ten million, is it twenty million? What does the exact count matter? There they are, and we are responsible. Tortures of hell, we are responsible! When I meet an unmaimed man of my generation, I want to shout at him: "How did you escape? How did you dodge it? What dirty trick did you play? Why are you not dead, trickster?” It is dreadful to have outlived your life, to have shirked your fate, to have overspent your welcome. There is nobody upon earth who cares whether I live or die, and I am glad of it, so glad of it. To be alone, icily alone. You, the war dead, I think you died in vain, I think you died for nothing, for a blast of wind, a blather, a humbug, a newspaper stunt, a politician's ramp. But at least you died. You did not reject the sharp, sweet shock of bullets, the sudden smash of the shell-burst, the insinuating agony of poison gas. You got rid of it all. You chose the better part. (Aldington, 1965 [1929]: 201)

The purpose of this self-excoriation is not atonement. It is an attempt at catharsis which finds little solace in survival and companionship. For Winter (1995: 5), 'the cutting edge of “modern memory”, its multi-faceted sense of dislocation, paradox, and the ironic, could express anger and despair, and did so in enduring ways; it was melancholic, but it could not heal'. Keightley and Pickering (2012: 167) posit that 'memory can become a creative resource once again, so reducing if not actually annulling the pain of the past, and enabling us to turn towards the future in less daunted fashion.' This accepts that healing, to pursue the bodily metaphor, tends to be imperfect: scars and vulnerabilities endure and for Aldington to forget would be a failure. Worthy sacrifice is elided by the new narrative epitomised by Aldington's novel, in which death is of one hero among many and heroism itself: fortitude has become the most heroic act of all, despite survival leading to guilt.

\section{Conclusion}

Remembering is bound up in social concerns: personal experiences, accumulated knowledge, narrative formations and their changes. Wertsch (2002: 46) notes that 'one of the few genuinely constant attributes of collective memory is that it is likely to undergo change.' The 
dominant social memory of the First World War changes quickly after the event, but then becomes entrenched so that dissenting viewpoints are forgotten, leading to the recent proliferation of books about reclaiming forgotten aspects of the conflict (Arthur, 2002; Barham, 2004; Levine, 2008; Sheffield, 2001; Woodward, 2006). This later reification is bound up in later twentieth-century conflicts which often drew on the First World War for their rhetoric. It had already become symbolic seventy years ago and now, Ann Rigney (2005: 14-15) observes, 'at a distance of almost a century, our shared memories of the First World War are above all the product of books, films, commemorative ceremonies and various other forms of representation.' The First World War is now for many a touchstone for events of unimaginable horror, understood through a highly selective range of primarily combatant writing. Phrases such as shell shock and No Man’s Land have passed into metaphor (Wilson, 2013), partly due to the interaction between memory and literature (Todman, 2005): it is no longer a living memory (Briggs, 2016), but still a dynamically changing one due to the proliferation of material made available by developing technologies (Brian et al, 2012). Authors who were virtually unknown during the war itself, such as Wilfred Owen, have become representative of the enduring social memory of the conflict, fitting better with twenty-first century myths than the likes of Raymond. To remember only war's horrors fails to address the insidious and pervasive structures which lead to mass acceptance of and participation in war: we might even read First World War literature using recent frameworks developed to process post-authoritarian rewritings of history (Dimbath and Wehling, 2016). A rich corpus of literature written in narrative modes that do not fit with the irrevocably disenchanted postmemory (Hirsch, 2012) of the First World War waits to be 'unforgotten.' In a period of increasing global tension, it is a reminder both of the public role of literature and history, and the difficulty of representing the social and political complexities of wartime. 


\section{References}

Aldington, R., 1965 [1929]. Death of a Hero, 1st UK unexpurgated ed. London: Consul. Anon, 1918a. The Election: Prime Minister on the Issues. The Times, 25 November, 9. Anon, 1918b. Mr. Lloyd George on His Task. The Times, 25 November, 13. Anon, 1924. New Books. Daily Mail, 25 April, 5.

Anon, 1925. The Use of Armistice Day. Manchester Guardian, 24 October, 12.

Arthur, M., 2002. Forgotten Voices of the Great War. London: Ebury.

Barham, P., 2004. Forgotten Lunatics of the Great War. New Haven, CT: Yale University Press.

Beiner, G., 2007. Remembering the Year of the French: Irish Folk History and Social Memory. Madison: University of Wisconsin Press.

Benjamin, W., 1999. The Storyteller: Reflections on the Works of Nikolai Leskov. In: Benjamin, Illuminations. Intro. H. Arendt. London: Pimlico, 82-107.

Bracco, R.M., 1993. Merchants of Hope: British Middlebrow Writers and the First World War, 1919-1939. Oxford: Berg.

Brian, É., Jaisson, M., and Mukherjee, S., 2012. Introduction: Social Memory and Hypermodernity. International Social Science Journal, 62 (203-204), 7-18.

Briggs, M.A., 2016. Dis/composing the First World War in Britain: Trauma and Commemoration in the Testimony of Harry Patch, 1998-2008. History \& Memory, 28 (1), 71-109.

Bullett, G., 1925. New Novels: Sixty-Four, Ninety-Four. Times Literary Supplement, 26 February, 136.

Clark, N.K. and Stephenson, G.M., 1995. Social Remembering: Individual and Collective Memory for Social Information. European Review of Social Psychology, 6 (1), 127-160.

Connolly, C., 1928. Review of Last Post. New Statesman, 4 February, 533.

Crumley, C.L., 2002. Exploring Venues of Social Memory. In: J.J. Climo and M.G. Cattell, eds. Social Memory and History: Anthropological Perspectives. Walnut Creek, CA:

Altamira Press.

de Groot, G., 1996. Blighty: British Society in the Era of the Great War. London: Longman. 
Dimbath, O., and Wehling, P., 2016. Exploring the Dark Side of Social Memory: Towards a Social Theory of Forgetting. In: G. Sebald and J. Wagle, eds. Theorizing Social Memories: Concepts and Contexts. London: Routledge, 138-156.

Dudziak, M.L., 2012. War-Time: An Idea, Its History, Its Consequences. Oxford University Press.

Eksteins, M., 1980. All Quiet on the Western Front and the Fate of a War. Journal of Contemporary History, 15 (2), 345-366.

Eksteins, M., 2000. Rites of Spring: the Great War and the Birth of the Modern Age. Boston: Houghton Mifflin.

Elton, O., 1929. C.E. Montague: a Memoir. London: Chatto \& Windus.

Erll, A., 2011. Memory in Culture. Trans. S.B. Young. Basingstoke: Palgrave.

Fentress, J. and Wickham, C., 1992. Social Memory. Oxford: Blackwell.

Frankau, G., 1919. Peter Jackson, Cigar Merchant. London: Hutchinson.

Fussell, P., 1975. The Great War and Modern Memory. Oxford University Press.

Grenfell, J., 1915. Into Battle. The Times, 28 May, 9.

Gregory, A., 1994. The Silence of Memory: Armistice Day 1919-1946. Oxford: Berg.

Gregory, A., 2008. The Last Great War: British Society and the First World War. Cambridge University Press.

Grieves, K., 1997. C.E. Montague and the Making of Disenchantment, 1914-1921. War in History, 4 (1), 35-59.

Hallam, E. and Hockey, J., 2001. Death, Memory and Material Culture. Oxford: Berg.

Haslam, S., 2002. Fragmenting Modernism: Ford Madox Ford, the novel and the Great War. Manchester University Press.

Halbwachs, M., 1980. The Collective Memory. Intro. Mary Douglas. New York: Harper \& Row.

Halbwachs, M., 1992. On Collective Memory. Ed. and trans. Lewis A. Coser. University of Chicago Press.

Hansen, J., 2015. Theories of Memory and the Imaginative Force of Fiction. In: S. Kattago, ed. Ashgate Research Companion to Memory Studies. Farnham: Ashgate, 197-208.

Hartley, L.P., 1926. Review of A Man Could Stand Up-. Saturday Review, 13 November, 592. 
Hervieu-Léger, D., 2000. Religion as a Chain of Memory. Trans. Simon Lee. Cambridge: Polity.

Hewer, C., and Roberts, R., 2012. History, Culture and Cognition: Towards a Dynamic Model of Social Memory. Culture \& Psychology, 18 (2), 167-183.

Hirsch, M., 2012. The Generation of Postmemory: Writing and Visual Culture After the Holocaust. New York: Columbia University Press.

Hynes, S., 1990. A War Imagined: The First World War and English Culture. London: The Bodley Head.

Isurin, L., 2017. Collective Remembering: Memory in the World and in the Mind. Cambridge University Press.

Keightley, E., and Pickering, M., 2012. The Mnemonic Imagination: Remembering as Creative Practice. Basingstoke: Palgrave Macmillan.

Langenmayr, F., 2016. Organisational Memory as a Function: The Construction of Past, Present and Future in Organisations. New York: Springer.

Leed, E., 1979. No Man's Land: Combat and Identity in World War I. Cambridge University Press.

Levine, J., 2008. Forgotten Voices of the Somme. London: Ebury.

Misztal, B.S., 2003. Theories of Social Remembering. Maidenhead: Open University Press.

Montague, C.E., 1922. Disenchantment. London: Chatto \& Windus.

Nevinson, H.W., 1928. Last Changes, Last Chances. London: Nisbet.

Nora, P., 1996. General Introduction: Between Memory and History. In: Nora, Realms of Memory: Rethinking the French Past. Ed. Lawrence D. Kritzman, trans. Arthur Goldhammer. New York: Columbia University Press, 1-20.

Olick, J., 2016. Sites of memory studies (Lieux des études de memoire). In: A.L. Tota and T. Hagen, eds. Routledge International Handbook of Memory Studies. London: Routledge, 41-52.

Pick, D., 1989. Faces of Degeneration: A European Disorder, c.1848-c.1918. Cambridge University Press.

Raymond, E., 1922. Tell England: a Study in a Generation. London: Cassell.

Rigney, A., 2005. Plenitude, scarcity and the circulation of cultural memory. Journal of European Studies, 35 (1), 11-28. 
Rigney, A., 2016. Cultural Memory Studies: Mediation, narrative, and the aesthetic. In: A.L. Tota and T. Hagen, eds. Routledge International Handbook of Memory Studies. London: Routledge, 65-76.

Saler, M., 2006. Modernity and Enchantment: A Historiographic Review. American Historical Review, 111 (3), 692-716.

Schwartz, B., 2016. Rethinking the Concept of Collective Memory. In: A.L. Tota and T. Hagen, eds. Routledge International Handbook of Memory Studies. London: Routledge, 921.

Sheffield, G., 2001. Forgotten Victory: The First World War: Myths and Realities. London: Headline.

Sherriff, R.C., 1968. No Leading Lady. London: Gollancz.

Sherriff, R.C., 2000 [1929]. Journey’s End. London: Penguin.

Srubar, I., 2016. Lifeworld and Trauma: Selectivity of Social Memories. In: G. Sebald and J. Wagle, eds. Theorizing Social Memories: Concepts and Contexts. London: Routledge, 2331.

Stevenson, R., 2013. Literature and the Great War. Cambridge University Press.

Taylor, R.A., 1928. Review of Last Post. Spectator, 4 February, 168.

Trott, V., 2016. “The market is getting flooded with them”: Richard Aldington's Death of a Hero and the War Books Boom. In: Nicola Wilson, ed. The Book World: Selling and Distributing British Literature, 1900-1940. Amsterdam: Brill, 95-116.

Todman, D., 2005. The Great War: Myth and Memory. London: Hambledon Continuum.

Walpole, H., 1925. The Novels of 1925. John O’London's Weekly, 5 December 1925, 373374.

Walters, E.C., 2016. Between Entertainment and Elegy: The Unexpected Success of R.C. Sherriff's Journey’s End (1928). Journal of British Studies, 55 (3), 344-373.

Ward, A.C., 1930. The Nineteen-Twenties: Literature and Ideas in the Post-War Decade. London: Methuen.

Watson, J.S.K., 2004. Fighting Different Wars: Experience, Memory, and the First World War in Britain. Cambridge University Press.

Wertsch, J.V. Voices of Collective Remembering. Cambridge University Press.

Wilson, R.J., 2013. Cultural Heritage of the Great War in Britain. Farnham: Ashgate.

Winter, J., 1995. Sites of Memory, Sites of Mourning: The Great War in European Cultural History. Cambridge University Press. 
Winter, J.M. and Sivan, E., 1999. Setting the Framework. In: Winter and Sivan, eds. War and Remembrance in the Twentieth Century. Cambridge University Press, 6-39.

Woodward, D., 2006. Forgotten Soldiers of the First World War: lost voices from the Middle Eastern Front. Stroud: Tempus.

Zerubavel, E., 2003. Time Maps: Collective Memory and the Social Shape of the Past. University of Chicago Press.

${ }^{1}$ While I focus on the novel here, I view social remembering as a more wide-ranging practice around the sharing of action, experience and performance (see e.g. Crumley 2002).

${ }^{2}$ H.M. Tomlinson to C.E. Montague, 20 February 1922. CEM/2/2/2/2. Tomlinson's novel on the war, All Our Yesterdays, was not published until January 1930; Aldington 1929: 7.

${ }^{3}$ C.E. Montague to Chatto \& Windus, 8 March 1927. University of Reading, Chatto \& Windus Archives, CW39/10. 